\title{
Latitudinal and local geographic mosaics in host plant preferences as shaped by thermal units and voltinism in Papilio spp. (Lepidoptera)
}

\author{
J. MARK SCRIBER \\ Department of Entomology, Michigan State University, 47 Natural Science Building, East Lansing, MI 48824-1115, USA; e-mail: \\ scriber@msu.edu
}

Key words. Butterflies, climate warming, degree days, diapause, "false-second" generation, introgression, oviposition preferences, Papilio glaucus, P. canadensis, North America, reproductive isolation, sex-linkage

\begin{abstract}
Laboratory and field tests support the "voltinism-suitability hypothesis" of host selection at various latitudes as well as in local "cold pockets": The best hosts for rapid development will be selected by herbivorous insects under severe thermal constraints for completion of the generation before winter. Papilio canadensis and P. glaucus females do select the best hosts for rapid larval growth in Alaska and in southern Michigan, but not in northern Michigan and southern Ohio. In addition to latitudinal patterns, local host preferences of $P$. canadensis are described in relation to "phenological twisting" of leaf suitability for larval growth in cold pockets with "thermally constrained" growing season lengths. White ash leaves (Fraximus americana) have the highest nutritional quality (relative to cherry, aspen, birch, and other local trees) throughout June and July for $P$. canadensis populations inside the cold pocket, but not outside. In all areas outside the cold pockets, even with bud-break occurring much later than other tree species, ash leaves rapidly decline in quality after mid-June and become one of the worse tree host species for larvae. This temperature-driven phenology difference creates a geographic mosaic in host plant suitability for herbivores. However, we also report here that the cold pocket of northern Michigan has basically disappeared since 1998. Implications of these changes are discussed in relation to voltinism and host plant selection.

Various physiological and ecological adaptations to thermal unit constraints are evident with both species of naturally hybridizing butterflies ( $P$. canadensis to the North and $P$. glaucus to the South). The rapid regional climate warming since 1998 in the Great Lakes region has allowed us to document some critical aspects of gene flow via analysis of independent "species-diagnostic" trait clines (including morphological, biochemical, and physiological characters). Narrower black bands on hind-wings, larger fore-wings, larval detoxification abilities for tulip tree leaves, behavioral preference of tulip tree leaves, and species-diagnostic allozymes such as PDG (x-linked) and HK (autosomal) provide evidence of these genodynamics. Laboratory hybridization studies (providing known reference groups) and field observations along the hybrid zone show that gene flow between $P$. glaucus and $P$. canadensis has recently been extensive across the historical hybrid zone.
\end{abstract}

\section{INTRODUCTION}

In high latitude locations of North America $\left(65^{\circ} \mathrm{N}\right)$, such as central Alaska, there are barely sufficient degree days above the developmental threshold for tiger swallowtail butterflies (Papilio species) to reach the diapausing pupal stage before winter. Numerous adaptations allow ecological success to be maximized under these limiting conditions (Ayres \& Scriber, 1994). One of these includes selection of the most nutritious host plant leaves for rapid larval growth in Alaska and other thermallyconstrained areas such as the local cold pockets of Michigan (Scriber, 1996a). Photoperiod-insensitive (obligate) diapause of pupae preventing a suicidal second generation is a characteristic for the entire $P$. canadensis (R \& J) species, even into the Great Lakes region between the USA and Canada and is X-linked as are several other traits such as aspen oviposition preferences (females are the heterozygous sex in butterflies; Rockey et al., 1987a; Scriber et al., 1991; Scriber, 1996b).

Two tiger swallowtail butterfly species (Lepidoptera: Papilionidae) are recognized in eastern North America; $P$. glaucus (L.), south of the Great Lakes (from $41^{\circ} \mathrm{N}$ to $26^{\circ} \mathrm{N}$ latitude) into Mexico and Florida and $P$. canadensis, across Canada to Alaska, $42-67^{\circ} \mathrm{N}$ latitude.
Although $P$. canadensis appears to be univoltine, with a sex-linked "obligate" diapause throughout its geographic range (all individuals diapause regardless of photoperiod), P. glaucus may have one to four generations annually with a "facultative" diapause (depending on latitude, length of the growing season, host plant quality, and photoperiod). The regulation of diapause induction in $P$. glaucus and $P$. troilus (predominantly photoperiod; Tidwell, 1995; Valella \& Scriber, 2002) and diapause termination (predominantly temperature; Deering et al., 2002; Scriber et al., 2002b) is likely to be a very complex mixture of environmental cues overlaid upon a genetic foundation of threshold responses (Tauber et al., 1986; Brakefield \& Reitsma, 1991; Bradshaw \& Holzapfel, 2001; Denlinger, 2002).

The number of generations for the southern multivoltine $P$. glaucus is determined by a combination of seasonal thermal unit accumulations, photoperiod, and host plant suitability. The northern limits to the bivoltine populations is roughly between $41-43^{\circ} \mathrm{N}$ (Scriber \& Lederhouse, 1992). In southern Michigan $\left(41.5-42.5^{\circ} \mathrm{N}\right)$, the average seasonal DD accumulations (during the years 1930-89) reflect enough thermal units for potential completion of two generations for the tiger swallowtail butterfly, $P$. glaucus, in most years: $1400-1500 \mathrm{C}$ seasonal DD 
totals (Scriber and Hainze, 1987). However, success of this second generation depends very much upon the choice of host plant species. On poor hosts such as paper birch, spicebush, sassafras, choke cherry, and white ash, the larvae at critical thermal zones fail to reach the pupal stage before the leaf quality severely declines (or abscission occurs). Some grow slowly in late summer and actually freeze to death as $4^{\text {th }}$ and $5^{\text {th }}$ instars as late as mid-October (Scriber \& Gage, 1995).

Trait clines have been documented to be quite stable to the north and south of the extensive butterfly hybrid zone from central Wisconsin and Michigan through New York State and Vermont since the early 1980s (Scriber, 1982, 1996b; Hagen et al., 1991; Scriber et al., 1996). While the variance in total summer DD accumulations across the Great Lakes region has been stable from the mid-1950s to 1990 , gradually increased warming during the last decade (except 1992) has been observed, particularly since 1998, when considerable northward introgression has been observed for a variety of traits (e.g. the capacity to detoxify tulip tree leaves; Scriber, 2002). In contrast, a trait not introgressing northward to the same extent is the occurrence of a "true" second generation. This paper examines oviposition preferences as well as voltinism potential in relation to geographic areas of differing thermal constraints for larval growth rates, with particular respect to recent Great Lakes regional climatic warming trends since 1998. Seasonal DD totals provide powerful predictive capabilities for identifying specific geographic areas that could experience sympatric and temporal overlap of these two swallowtail butterfly species. Assessing differential rates of introgression for previously concordant trait step-clines has also been possible in relation to local DD accumulations.

\section{Cold pocket dynamics and the "voltinism-suitability" model of host plant suitability}

The "voltinism-suitability hypothesis" (Scriber \& Hainze, 1987; Nylin 1988; Scriber \& Lederhouse, 1992) postulates that ovipositing females will select the most nutritious host plant species. In this paper, the hypothesis is evaluated using field and laboratory studies of oviposition behavior.

In climatic cold pockets of northern Michigan, the average freeze-free period of summer growth was only 70 days (and in $10 \%$ of the years, it was only 40 days; Scriber, 1994). For the 50 years from 1930-1979, the average dates for the last spring freezes were June $5^{\text {th }}-25^{\text {th }}$ (or as late as July $10^{\text {th }}$ in $10 \%$ of the years). Combined with the early fall freezes in this same area (August $25^{\text {th }}$ on the average, but August $15^{\text {th }}$ in $10 \%$ of the years), larval growth was severely constrained. This local climatic region has had a similar plant hardiness zone rating as central Alaska and even looks similar to Alaska, with stunted black spruce, larch, paper birch, balsam poplar, and aspen.

However, unlike the situation in Alaska, the immediate surrounding area (only $50-100 \mathrm{~km}$ outside) of the cold pockets is much warmer, averaging 90-125 freeze-free days with more than sufficient seasonal DD to easily sup- port the completion of the life stages of the univoltine $P$. canadensis (over the 5 decades from 1930-1980; Scriber, 1994). As with the general continent-wide latitudinal bands pattern of thermal constraints alternating with warmer bands in latitudes to the south with " relaxed" selection pressures (Scriber \& Lederhouse, 1992), it was postulated that the cold pockets would operate the same way (locally and longitudinally, as well as latitudinally; Scriber, 1996a). To assess the hypothesized adaptations of these populations, we sampled transects of these Michigan cold pockets and surrounding areas during the last decade. These results are reported here for the first time.

One obvious concern for this latitudinally-based host preference model (Scriber \& Lederhouse, 1992) is that host leaf quality does not remain constant throughout the season. Phenologically-distinct water relations early in the season (bud-break) have both ecological and evolutionary implications for univoltine tree-hoppers (Wood et al., 1990) and other tree-feeders (Scriber, 1984; Mattson $\&$ Scriber, 1987). Seasonal rates of decline in nutritional quality (i.e. increase in leaf toughness and decline in nitrogen and water) are basically predictable and unique for different tree species (Slansky \& Scriber, 1985). These phenological patterns are very closely correlated with summer DD accumulations. However, such patterns may be interrupted in local cold pockets. The interaction between the local abiotic thermal unit accumulations and host preferences is examined here to understand how local cold pockets may create a shifting geographic mosaic of host quality for polyphagous Papilio species. This is called the phenological twist concept of host suitability in cold pockets.

\section{METHODS}

To evaluate the voltinism-suitability hypothesis in natural populations, field counts of eggs and larvae were conducted over 2 years in areas with large populations of $P$. canadensis in Charlevoix County of northern Michigan (with ample DD for one generation) and also in areas with populations of $P$. glaucus from Ingham and St. Joseph Counties of southern Michigan (where thermal constraints prevent successful completion of two generations on any but the best host species). One year of field eggs/larval counts were also conducted in Fairbanks, Alaska (where severe constraints exist even for completing a single generation; Ayres and Scriber, 1994). Successive trees of all plant species ever recorded as natural hosts for these butterflies were intensely examined on leaves 1-2 meters above the ground, along hedgerows, roadsides, and streams where swallowtails were easily seen flying and ovipositing. Previous observations (Grossmueller and Lederhouse, 1985) have shown that most of the eggs of $P$. glaucus and $P$. canadensis are laid at these heights. All eggs and larvae as well as the total number of Michigan leaves examined in both years were recorded for each of the 11 species in the north and 9 species in the south.

To evaluate the voltinism-suitability hypothesis for individual females, laboratory oviposition preferences were determined for field-captured females using stacks of clear round plastic arenas on rotating platforms in front of incandescent lights (Scriber, 1993). Nine host plant species were used in female host choice studies for $P$. glaucus (Prunus serotina, P. virginiana, Betula papyrifera, Liriodendron tulipifera, Fraximus americana, Tilia 
TABLE 1. Field searches (1992-1993) for wild eggs of $P$. glaucus in southern Michigan (Ingham County \& St. Joseph County) and northern Michigan (the univoltine P. canadensis). Fairbanks, Alaska counts were made in 1992 and 1995 (Salix novae-angliae $=S$. monticola). Host species within each region are sorted (top to bottom) from most nutritionally suitable to least based on replicated laboratory growth rate studies. Abundance of eggs is expressed as leaves/egg (= average number of leaves searched per egg found) and leaf units/egg (= average number of $40 \mathrm{~cm}^{2}$ leaf units searched per egg found). For trees with compound leaves (e.g. Fraxinus americana), each leaflet was considered as a separate leaf. Specialization is evident under thermal constraint in southern Michigan, whereas generalization occurs in northern Michigan.

\begin{tabular}{|c|c|c|c|c|}
\hline & Eggs/larvae found & $\begin{array}{l}\text { Leaves searched per } \\
\text { insect }\end{array}$ & Mean leaf area $\left(\mathrm{cm}^{2}\right)$ & $\begin{array}{c}\text { Leaf units }\left(40 \mathrm{~cm}^{2}\right) \text { per } \\
\text { insect }\end{array}$ \\
\hline \multicolumn{5}{|c|}{ P. glaucus (MI): Two generations with phenological constraints (Okemos, E. Lansing, southern MI; latitude 42.5 N). } \\
\hline Ptelea trifoliata & 41 & 747 & 28 & 523 \\
\hline Liriodendron tulipifera & 41 & 463 & 112 & 1,296 \\
\hline Prumus serotina & 42 & 1,199 & 33 & 3,358 \\
\hline Sassafras albidum & 1 & 29,311 & 35 & 25,647 \\
\hline Fraxinus americana & 4 & 13,260 & 37 & 12,265 \\
\hline Tilia americana & 1 & 11,993 & 98 & 29,383 \\
\hline Amelanchier sp. & 0 & $\infty$ & 18 & $\infty$ \\
\hline Prumus virginiana & 0 & $\infty$ & 25 & $\infty$ \\
\hline Lindera benzoin & 0 & $\infty$ & 22 & $\infty$ \\
\hline \multicolumn{5}{|c|}{ P. canadensis (MI): One generation: No phenological constraints (Charlevoix County in northern MI; latitude $45.2 \mathrm{~N}$ ). } \\
\hline Prumus serotina & 11 & 3,717 & 33 & 3,066 \\
\hline Prumus pensylvanica & 1 & 8,880 & 30 & 6,660 \\
\hline Prumus virginiana & 2 & 5,370 & 25 & 3,556 \\
\hline Populus balsamifera & 2 & 7,650 & 46 & 8,798 \\
\hline Populus tremuloides & 4 & 3,970 & 17 & 1,687 \\
\hline Populus grandidentata & 8 & 1,081 & 32 & 864 \\
\hline Amelanchier sp. & 8 & 2,217 & 18 & 998 \\
\hline Betula papyrifera & 1 & 9,935 & 25 & 6,209 \\
\hline Fraxinus americana & 5 & 1,148 & 37 & 1,062 \\
\hline Tilia americana & 0 & $\infty$ & 98 & $\infty$ \\
\hline Almus rugosa & 0 & $\infty$ & 70 & $\infty$ \\
\hline \multicolumn{5}{|c|}{ P. canadensis: One generation with constraints (central AK; latitude $65 \mathrm{~N}$ ). } \\
\hline Populus balsamifera & 5 & 3271 & 46 & 3761 \\
\hline Almus temuifolia & 5 & 2643 & 84 & 5550 \\
\hline Populus tremuloides & 9 & 1771 & 17 & 753 \\
\hline Salix monticola & 9 & 1989 & 18 & 895 \\
\hline Salix alaxensis & 1 & 16,952 & 37 & 15,681 \\
\hline Salix glauca & 0 & $\infty$ & 22 & $\infty$ \\
\hline Betula resinifera & 0 & $\infty$ & 19 & $\infty$ \\
\hline Almus crispa & 0 & $\infty$ & 72 & $\infty$ \\
\hline
\end{tabular}

americana, Ptelea trifoliata, Lindera benzoin, Sassafras albidum) and also as reported for $P$. canadensis $(P$. serotina, $P$. virginiana, Populus tremuloides, $P$. balsamifera, $T$. americana, $B$. papyrifera, Amelanchier canadensis, Alnus rugosa, $F$. americana). These leaves were offered in 5-choice arenas and resulting choices by ovipositing females were standardized relative to $100 \%$ of tulip tree for $P$. glaucus and $100 \%$ of quaking aspen for $P$. canadensis. These plant reference standards (tulip tree and quaking aspen) were present in the arenas with 4 other hosts for butterfly individuals of the respective species in both their first and second set of 5-choice leaf arrays. Some Michigan butterflies were taken to Alaska for oviposition preference bioassays on Alaskan host species (and some Alaskan butterflies were taken to Michigan for assays on Michigan plants).

\section{Larval rearing and pupal emergence}

Offspring of each female were randomly allocated across different plant species as treatments and individually reared on field-collected host plant leaves in controlled environment chambers separately at $23-25^{\circ} \mathrm{C}$ with $16: 8$ hour photoperiods until pupation. Pupae were placed in screened cylinders individually after weighing and allowed to stay at these conditions for 6-8 weeks for adult eclosion. Those not eclosing in this period were considered to be in diapause and were moved to storage at $4-5^{\circ} \mathrm{C}$ in darkness until the next season.

Hybrid and backcrosses of hybrids to parental types were obtained by hand pairing virgin lab-reared females with fieldcaptured or lab-reared males. After they were placed in screen cylinders and covered, copulating pairs were allowed to separate at will, generally after about 45 minutes to an hour (Stump, 


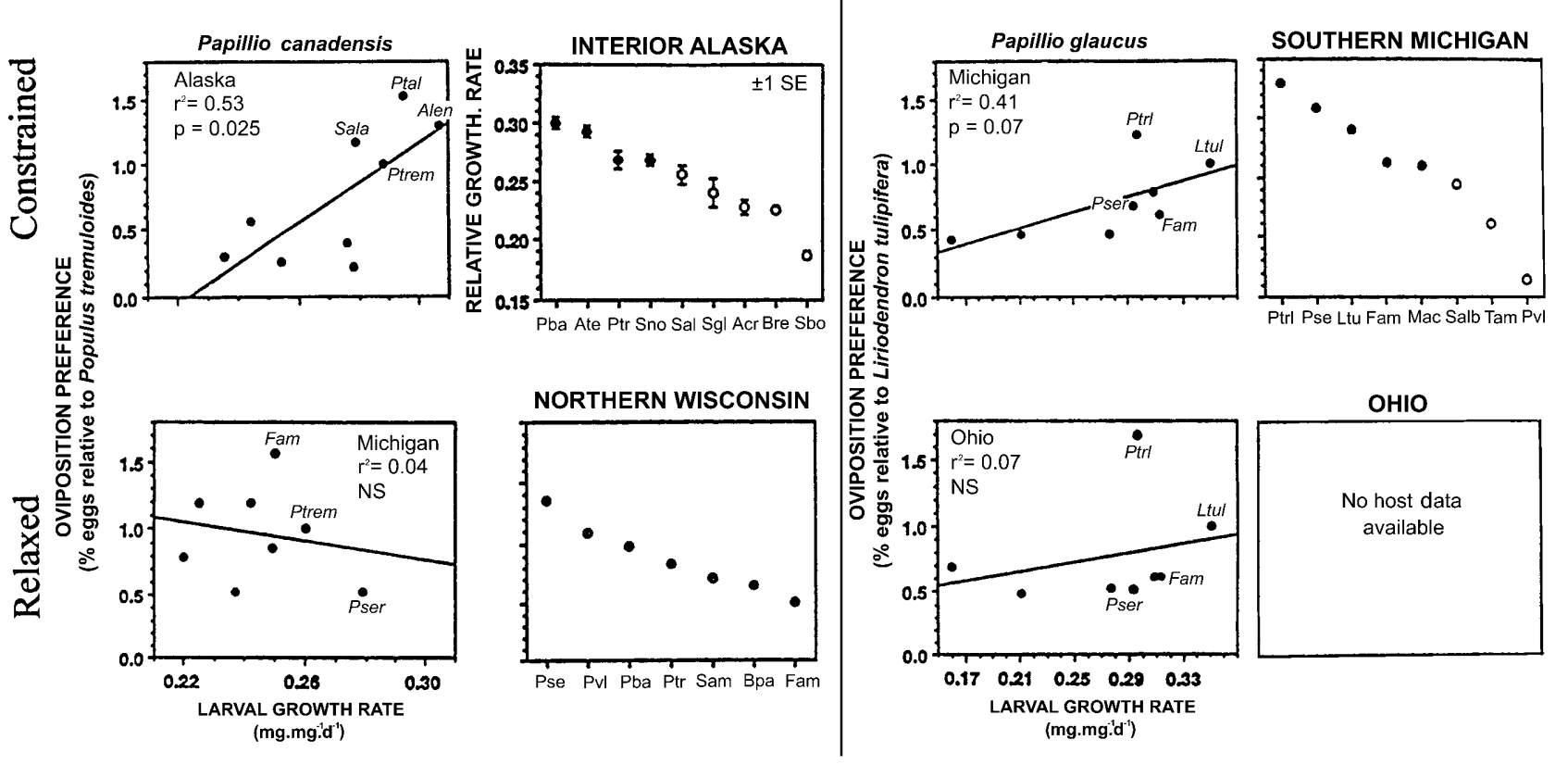

Fig. 1. Comparisons of Relative Growth Rates (RGR) of larvae, where RGR $=\mathrm{mg} /(\mathrm{mg} \times$ day), and multi-choice oviposition preferences of females (mothers) from four geographic sites at different latitudes. LEFT SIDE (top and bottom, respectively) represents $P$. canadensis populations from interior Alaska (Fairbanks, where severe thermal constraints exist for completion of even a single generation) and northern Michigan/Wisconsin (without constraints on completeing a single generation on various of their potential host plants. RIGHT SIDE (top and bottom, respectively) represents similar comparisons are depicted for $P$. glaucus in southern Michigan ("constrained" thermally) and southern Ohio (not "constrained"). Documented host plants from the literature are indicated (as darkened symbols) for the first 3 sites, but not for southern Ohio which has not been thoroughly searched (see also Scriber \& Lederhouse, 1992). Host plant abbreviations for Genus (first letter) and species (next 2-3 letters) from plants in Table 1.

2000). The female would then be set up in oviposition bioassays in rotating round plastic boxes on platforms in front of a bank of lights to stimulate oviposition (Scriber, 1993). Eggs were collected and females fed $10-15 \%$ honey water daily. Neonate larvae were transferred immediately after hatching to rearing containers with host leaves and reared to pupation under controlled environment conditions $\left(23-25^{\circ} \mathrm{C}, 16 \mathrm{~L}: 8 \mathrm{D}\right)$. Pupae were weighed on a semi-macroanalytical balance to nearest $0.1 \mathrm{mg}$ and set up individually in small screened cylindrical cages with $150 \mathrm{~mm}$ diameter plastic petri dishes as end-covers. Adults eclosed directly within two to four weeks and climbed up the screen, allowing the wings to fully expand. Those not eclosing as adults within 8 weeks were moved to coolers at $4-5^{\circ} \mathrm{C}$ and total darkness for five to six month diapause period. These were brought out of storage and set up for emergence the following season.

\section{Diagnostic allozymes}

The frequencies of LDH (lactate dehydrogenase), PGD (phosphogluconate dehydrogenase), and HK (hexokinase) allozymes were determined because these have basically been speciesdiagnostic. Both LDH and PGD were known from our previous studies to be X-linked, while HK is autosomal (Hagen \& Scriber, 1989). Standard procedures were used for cellulose acetate electrophoresis (Hagen \& Scriber, 1991; modified only slightly; see Stump, 2000).

\section{Field leaf collections}

Leaf samples from northern Michigan were taken at weekly intervals across the statewide northern transect of the cold pockets. These samples (4-6 leaves from 3 parts of the lower branches of 3-5 trees from each location) were immediately placed into air-tight zip-lock plastic bags and kept on ice for transport to the laboratory for weighing wet, oven-drying at $38-42^{\circ} \mathrm{C}$, and reweighing. Leaf water contents $(\%)$ were calculated and used as an index of leaf quality as has been shown throughout the season (Scriber, 1984).

\section{Determining local seasonal thermal unit accumulations (growing degree days)}

The average thermal unit accumulation during the growing season (above a base developmental threshold $10^{\circ} \mathrm{C}$ (or $50^{\circ} \mathrm{F}$ ) for P. glaucus and P. canadensis; Scriber \& Lederhouse, 1983, 1992) has been recorded by more than 30,000 stations across the northeastern United States, predominantly for use in crop growing PM predictions. The average growing $\mathrm{DD}$ accumulations (above a base $50^{\circ} \mathrm{F}$ used for corn production models) also precisely reflect the thermal unit accumulations of relevance for $P$. glaucus and $P$. canadensis larval development and voltinism patterns (as well as European corn borers and other insects; Beck, 1980; Scriber \& Hainze, 1987). Historical DD accumulations above $50^{\circ} \mathrm{F}$ for the northeastern United States were collected by Zedex, Inc. and run in a GIS spatial program with interpolation to $1 \mathrm{~km}^{2}$ to illustrate the precise distribution of seasonal thermal unit accumulations (March $1^{\text {st }}$-October $31^{\text {st }}$ ) for selected years and decades.

\section{RESULTS}

\section{Voltinism-suitability hypothesis (lab and field tests)}

The voltinism-suitability hypothesis suggesting latitudinal specialization on "fast growth" hosts was evaluated for Alaska versus northern Michigan in laboratory and field studies. Multi-choice oviposition preference studies were conducted here with $P$. canadensis females from Alaska and northern Michigan using two 5-choice host arenas ( 9 plant species with quaking aspen as the control, 

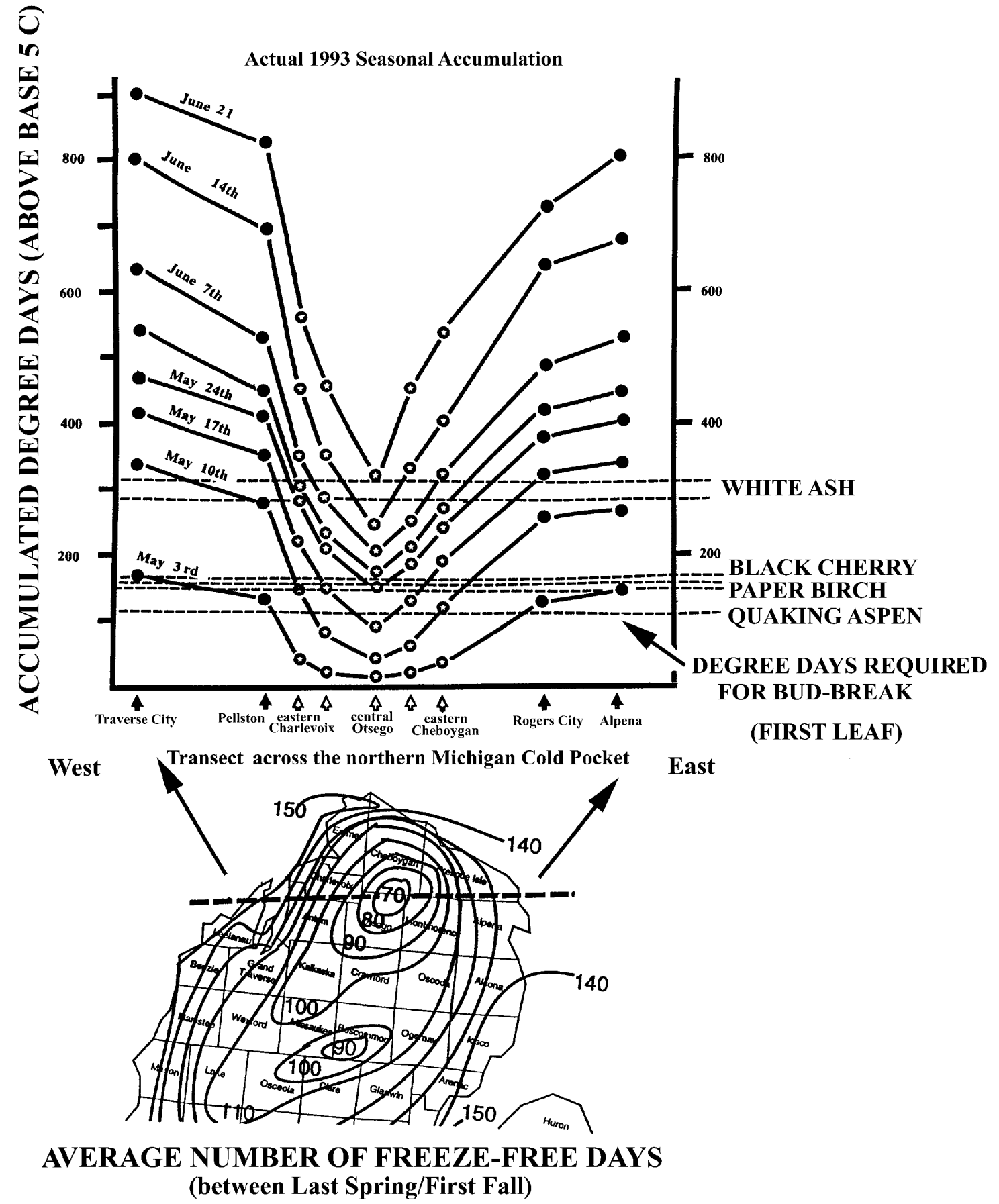

Fig. 2. The cold pocket transect showing the plant growing degree days (base $5^{\circ} \mathrm{C}$ ) and the delayed first leaf (bud-break) thresholds of white ash (F. americana) relative to black cherry, paper birch, quaking aspen (adapted from Lechowicz, 1984). Note that at the edges, bud break of ash is only about 1 week behind the others (May 3-May $10^{\text {th }}$ in this year) however, in the cold pocket center, bud-break may be 4-6 weeks behind the others (compare also Fig. 3). A transect across from Traverse City to Alpena reflects delayed ash leaves with water contents $65.5 \%(0.7 \mathrm{sd})$ in the center at Vanderbilt, versus $60.0 \%$ and less at the edges as late as July $8^{\text {th }}(1993)$. On that date big-toothed aspen leaves $(P$. grandidentata) have already less than $55 \%$ water in Vanderbilt and of considerably lower quality than the delayed ash leaves (as are black cherry, quaking aspen, and paper birch leaves).

occurring in both arenas). The Alaska females (having experienced constrained thermal regimes as a population) showed the greatest oviposition preferences for $P$. balsamifera, Alnus tenuifolia, Salix alaxensis, and P. tremuloides. These four Alaskan favorites were the four best hosts for rapid larval growth (RGR data from Ayres et al.,
1991; Ayres \& Scriber, 1994). The correlation of preference and larval growth rates was significant $(\mathrm{r}$-squared $=$ $0.53 ; \mathrm{p}=0.025 ;$ Fig 1 ). These lab preferences correspond closely with the natural choice of host species historically reported for Alaska (Scriber \& Lederhouse, 1992) and also with the preliminary (single season) egg/larval/leaf 
counts in Fairbanks, Alaska (Table 1). Outside the cold pocket in northern Michigan where thermal constraints are relaxed (completion of one generation is possible on every host species), no significant correlation in lab bioassays was observed for oviposition preferences of females with larval growth rates for the host species offered (r-squared $=0.04$, ns; Fig 1; all larvae on Alnus died, thus only 8 other species are figured). Natural host choices of females in northern Michigan also showed little evidence of any local specialization in field leaf examinations (Table 1).

In contrast, females from the thermally constrained population of $P$. glaucus in southern Michigan show strong preferences and natural host plant specialization on hop tree ( $P$. trifoliata, of the Rutaceae), tulip tree ( $L$. tulipifera, of the Magnoliaceae) and on black cherry ( $P$. serotina, of the Rosaceae) in both the lab and field, with only sporadic or non-documented natural use of the 6 other tree species (Table 1; top). More than $95 \%$ of all eggs detected in the field over this 2-year period were from these 3 host species (those supporting the fastest growth). In contrast, the southern Ohio populations have historically always had (at least the past few decades) sufficient thermal unit accumulations to complete two generations on all acceptable host plant species and there is no correlation with female oviposition choice and host suitability for larval growth (Fig. 1; bottom right). While intensive leaf searches have not been done in Ohio as in the other populations, we have noted there larvae of $P$. glaucus in the field feeding on spicebush (L. benzoin), which is the worse host plant species for larval growth of those ever reported to be eaten by the larvae. Preliminary leaf searches in Ohio (1995) required only an average of 1096 white ash leaves to find an egg or larva of $P$. glaucus (Lederhouse \& Scriber, unpubl.). In contrast, 12 265 leaves of ash were required in southern Michigan (Table 1). Even though a poor larval host, Ohio females used ash more than those in Michigan.

It seems from these results that "preference / performance" correlations are clearly affected by abiotic factors such as annually variable thermal units for local populations of these two swallowtail butterfly species. Local and temporal variation, unpredictability, as well as host plant variation in phytochemistry and natural enemy populations are known to alter "suitability" and may partially explain why expected correlations between adult host preferences and larval growth performances are not more common (Futuyma, 1976; Thompson, 1988, 1996; Mopper, 1996; Bossart \& Scriber, 1999; Yamaga and Ohgushi, 1999; Redman \& Scriber, 2000; Cronin et al., 2001). The time required for local host plant preferences to evolve is difficult to determine from short term field studies, thus geographic comparisons or "transplant" studies are useful.

Michigan females of $P$. canadensis were taken to Alaska for bioassays on Alaskan hosts and Alaskan females were taken to northern Michigan for bioassays on Michigan plants as an experimental cross-check on differential adaptation to local favorites. The Michigan females $(\mathrm{n}=4)$ failed to avoid the poor quality hosts (Alnus crispa and Betula resinifera) as did Alaskan females (Table 3). In 1992, the differences for Michigan versus Alaska populations were significant ( $24.8 \%$ versus $8.9 \%$ of eggs on Alnus crispa, $\mathrm{t}=0.023$; and $17.5 \%$ versus $4.9 \%$ for Betula resinifera, $\mathrm{t}=0.034$ ). The maladapted preference for these two "bad" hosts by novice Michigan females was verified by the larval growth rates for Michigan larvae $(\mathrm{RGR}=0.400+/-0.049$ on Acr; and $0.381+/-$ 0.033 on Bre), which were even poorer than the Alaskan larvae $(\mathrm{RGR}=0.454+/-0.071$ on Acr; and $0.408+/-$ 0.020 on Bre; see Ayres \& Scriber, 1994).

Alaskan populations that do naturally contact Populus tremuloides, never contact Betula papyrifera, Prunus serotina, Tilia americana or Fraxinus americana which grow in northern Michigan. Fraxinus americana (white ash) is the favorite for local northern Michigan populations of $P$. canadensis (Scriber, 1996a). However, Alaskan females (never exposed to ash) fail to recognize its excellent quality for rapid larval growth, and lay a significantly smaller proportion of their eggs on it $(14.5 \%)$ than do Michigan females (34.3\% in non-cold-pocket areas; and $53.0 \%$ in cold pockets; Table 4 ). These differences of Alaska and Michigan are significant (T-tests at 0.002 and 0.001, respectively). Even though Betula papyrifera (unlike $B$. resinifera) is of excellent quality for larval growth of Alaskan individuals ( $\mathrm{RGR}=0.442+/-$ 0.026 versus $0.448+/-0.020$ for Michigan larvae), they avoid oviposition on it (only $6.6 \%$ total eggs; Table 4 ).

\section{Cold pocket phenological twists}

In testing the voltinism-suitability hypothesis with $P$. canadensis, it was discovered that local climatic cold pockets in northern Michigan (Fig. 2) showed white ash ( $F$. americana, of the Oleaceae) as the favorite for oviposition over the other 8 species (Fig. 1). The extreme phenological delay in bud-break and leaf maturation of ash in the center of the cold pocket (4-5 weeks later than cherry, aspen, and birch; Fig. 2) relative to areas outside, resulted in ash being the most nutritious plant throughout June and July at this location only (outside the cold pockets the rapidly maturing ash leaves quickly become one of the poorest hosts for rapid larval growth; Fig. 3; Scriber, 1996a).

In Michigan, white ash (and other Fraxinus species) rapidly declines in quality immediately after the leaves have fully expanded, which results in low nutritional quality for the rest of the season (mid-May through abscission in September) in southern Michigan. However, because of delayed bud-break (at $300 \mathrm{C}$ DD, with a base $5^{\circ} \mathrm{C}$ plant growth threshold; Lechowicz, 1984) combined with slow leaf expansion of ash relative to other host plant species such as cherry (Prumus species), basswood (Tilia), paper birch (Betula) and quaking aspen (P. tremuloides), or balsam poplar ( $P$. balsamifera), ash actually provided the highest quality leaves for larval growth in the cold pockets for most of the growing season (midJune to late July; Figs 1 \& 3). Outside of these coldest areas, ash leaves have already rapidly declined in nitrogen (from $>4 \%$ to $2.3 \%$ ) and water (from $75 \%$ to $58 \%$ in 


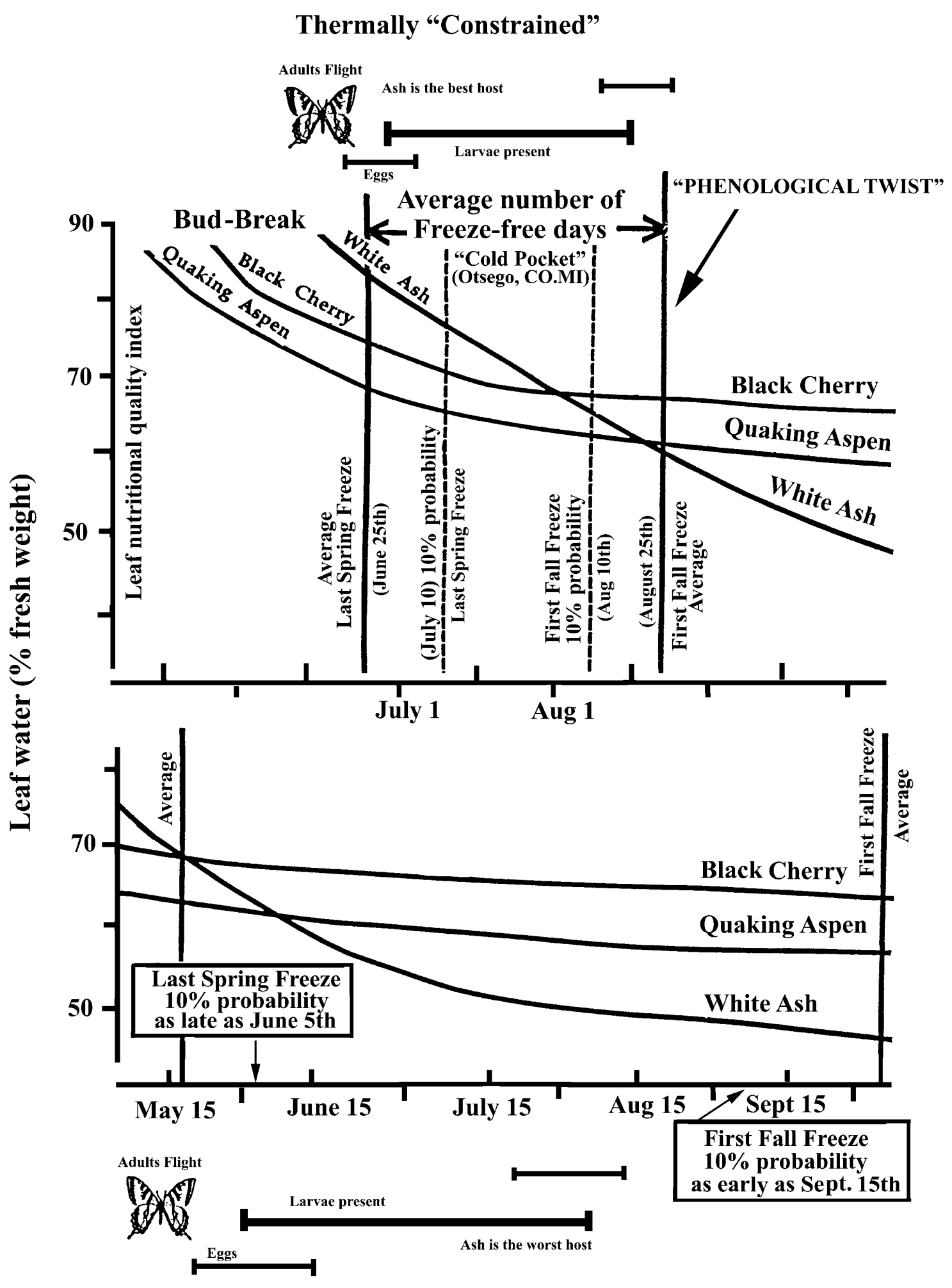

Thermally "Relaxed"

Fig 3. The "phenological twist" model for ash suitability relative to that of black cherry and quaking aspen, as indexed by leaf water content. Outside the "cold pocket" and further south in Michigan, the season is functionally much longer for $P$. canadensis larvae to complete development before leaf senescence and freezing temperatures. Approximately 55-75 freeze-free days exist outside (bottom of figure) compared to 35 or fewer days inside (top of figure). Ash in the cold pocket supports the fastest Papilio growth $(0.76 \mathrm{mg} / \mathrm{mg}$ per day; compared to 0.68 and 0.57 for cherry and aspen, mean of offspring of 4 females respectively). However, outside the cold pocket ash is one of the worst hosts for later instars of larval growth $(0.09 \mathrm{mg} / \mathrm{mg}$ per day; compared to 0.14 and 0.11 for cherry and aspen; means of 20 families; Scriber 1991). 
TABLE 2. Differential larval growth rates of surviving Papilio glaucus in southern Michigan on 4 host plant species of different nutritional quality. These larvae represent the survivors after 24 days of field predation (in late August 1992 near Okemos, Michigan). Individual trees (9-24) of each of the 4 plant species initially received totals 10-20 larvae (totals of 90-240 neonate larvae per tree species).

\begin{tabular}{lccc}
\hline $\begin{array}{l}\text { Plant species *** } \\
(\mathrm{mg})\end{array}$ & $\begin{array}{c}\text { Number of } \\
\text { surviving } \\
\text { larvae } \\
(\mathrm{N})\end{array}$ & $\begin{array}{c}\text { Developmental } \\
\text { index* }\end{array}$ & Live weight \\
\hline Tulip tree & $(11)$ & $4.55(0.14)$ & $708.8(142.1)$ \\
Hop tree & $(17)$ & $4.15(0.15)$ & $359.8(50.1)$ \\
Black cherry & $(4)$ & $4.38(0.24)$ & $314.3(66.4)$ \\
White ash & $(7)$ & $3.64(0.14)$ & $187.5(51.0)$ \\
\hline
\end{tabular}

*Developmental index is the mean instar ( e.g. $4^{\text {th }}$ instar $=4.0$, $5^{\text {th }}$ instar $=5.0$, and a molt $4^{\text {th }} / 5^{\text {th }}=4.5$ )

**Tulip tree (Liriodendron tulipifera), Hop tree (Ptelea trifoliata), Black cherry (Prunus serotina), and white ash (Fraxinus americana).

early June), having actually become a much poorer host than cherries, aspens, and birch for fast larval growth of P. canadensis in the north (Scriber, 1991).

This delayed phenological twist of ash quality locally inside the cold pockets may explain the surprisingly strong oviposition preferences for ash leaves of Papilio females here as opposed to adjacent areas outside of the colder location with early phenological twists lowering ash quality (Scriber, 1996a). With rapid maturation inside as well as outside the cold pocket for other tree species, there was a lack of such significant seasonal differences in the patterns of relative leaf quality for cherry species, aspens, and birch (Fig. 3; Giroux, 1998). For example, on 8 June 1993, two cold pockets sampling sites had bigtoothed aspen (Populus grandidentata) leaves already with water contents less than $50 \%$ which was similar to the other transect sites outside the cold pocket. Quaking aspen also had similar water contents (57-59\%) at all sites including the 2 cold pocket locations. In contrast, the tender, recently emerged white ash leaves in the two cold pocket sites (Otsego County) had the highest water content of all sites (64-67\%), with phenologically-advanced transect edge sites (Traverse City and Alpena) possessing more mature leaves with $60-61 \%$ water.

This phenological twist in ash suitability relative to other host species shown here is caused by different rates of DD accumulations and differential budbreak thresholds and leaf maturation rates of various plant species. A geographical transect of the cold pocket region conducted here illustrates the low thermal accumulation rates and low total DD for the center versus surrounding areas (Fig. 2). The reason for the phenological twist in leaf nutritional quality for ash in the center versus at edges of the pocket is related to the temporal delay in bud-break of ash compared to different species as illustrated along the transect (Fig. 2). Implications for voltinism limits are illustrated for butterfly larvae in northern Michigan in July-August (Fig. 3, top) versus those in May-June and July-August down in south-central Michigan (or outside the cold pocket; Fig. 3, bottom). Larvae on ash leaves will do poorly and may not complete development to the diapausing pupal stage in thermally constrained areas near latitudes of $41-43^{\circ} \mathrm{N}$ (Scriber \& Lederhouse, 1992) or cold pockets (Scriber, 1996a). Slow larval growth for $P$. glaucus in southern Michigan was observed on ash relative to cherry, tulip tree, and hop tree (Table 2). Larvae on tulip tree gain weight at nearly $4 \mathrm{X}$ the rate on ash (Table 2).

\section{True second generation lags behind other northward introgressing traits}

A true second generation, derived from the first one for that year, will not occur in cases where individuals carry the sex-linked obligate diapause gene (in homozygous combinations for males and hemizygous for females; Rockey et al., 1987a). Even with facultative diapause and bivoltine potential, a second generation of $P$. glaucus (or heterozygous hybrid males with one obligate diapause gene) is likely not to occur where DD accumulations are constrained to less than $2800 \mathrm{~F}$ regardless of the latitude and corresponding photoperiod (Ritland \& Scriber, 1985; Hagen \& Lederhouse, 1985). With extensive new data presented here for the 1987-2001 period, we see that this juncture with the northernmost populations that show some consistent (and true) second generations lies at the southernmost edge of the hybrid zone, corresponds to regions with 2900-3100 F DD of thermal unit accumulations (Scriber, in prep.).

\section{DISCUSSION}

\section{Latitudinal variation in preferences supports voltinism - suitability hypothesis}

The voltinism-suitability hypothesis is generally supported by behavioral preference data from the field observations, as well as from the laboratory experiments

TABLE 3. Primary 5-choice array of Alaskan plants ${ }^{1}$ for oviposition preferences. Data presented as means ( \pm SE).

\begin{tabular}{|c|c|c|c|c|c|c|c|}
\hline Location \& year & Females & Ate & Ptr & $\mathrm{Sg} 1$ & Acr & Bre & Eggs (n) \\
\hline Alaska 1991 & (5) & $\begin{array}{r}43.3 \\
\pm 5.6\end{array}$ & $\begin{array}{r}33.4 \\
\pm 5.7\end{array}$ & $\begin{array}{r}12.6 \\
\pm 5.3\end{array}$ & $\begin{array}{r}5.8 \\
\pm 2.0\end{array}$ & $\begin{array}{r}5.0 \\
\pm 2.2\end{array}$ & $\begin{array}{r}44.2 \\
\pm 9.5\end{array}$ \\
\hline 1992 & (21) & $\begin{array}{r}34.7 \\
\pm 6.8\end{array}$ & $\begin{array}{r}35.7 \\
\pm 6.6\end{array}$ & $\begin{array}{r}15.5 \\
\pm 4.8\end{array}$ & $\begin{array}{r}8.9 \\
\pm 3.2\end{array}$ & $\begin{array}{r}4.9 \\
\pm 1.8\end{array}$ & $\begin{array}{r}28.9 \\
\pm 3.3\end{array}$ \\
\hline 1995 & (2) & $\begin{array}{r}24.6 \\
\pm 18.7\end{array}$ & $\begin{array}{r}53.7 \\
\pm 40.4\end{array}$ & $\begin{array}{r}20.0 \\
\pm 20.0\end{array}$ & $\begin{array}{l}0.0 \\
0.0\end{array}$ & $\begin{array}{r}1.7 \\
\pm 1.7\end{array}$ & $\begin{array}{r}23.5 \\
\pm 6.5\end{array}$ \\
\hline Michigan 1992 & (4) & $\begin{array}{r}23.8 \\
+11.4 \\
\end{array}$ & $\begin{array}{r}25.3 \\
\pm 6.6 \\
\end{array}$ & $\begin{array}{r}8.7 \\
+3.0 \\
\end{array}$ & $\begin{array}{r}24.8 \\
\pm 10.5 \\
\end{array}$ & $\begin{array}{r}17.5 \\
\pm 9.6\end{array}$ & $\begin{array}{r}42.0 \\
\pm 10.9\end{array}$ \\
\hline
\end{tabular}

${ }^{1}$ Ate $=$ Alnus tenuifolia, $\mathrm{Ptr}=$ Populus tremuloides, $\mathrm{Sgl}=$ Salix glauca, Acr $=$ Alnus crispa, Bre $=$ Betula resinifera. 


\section{Disappearing cold pocket}

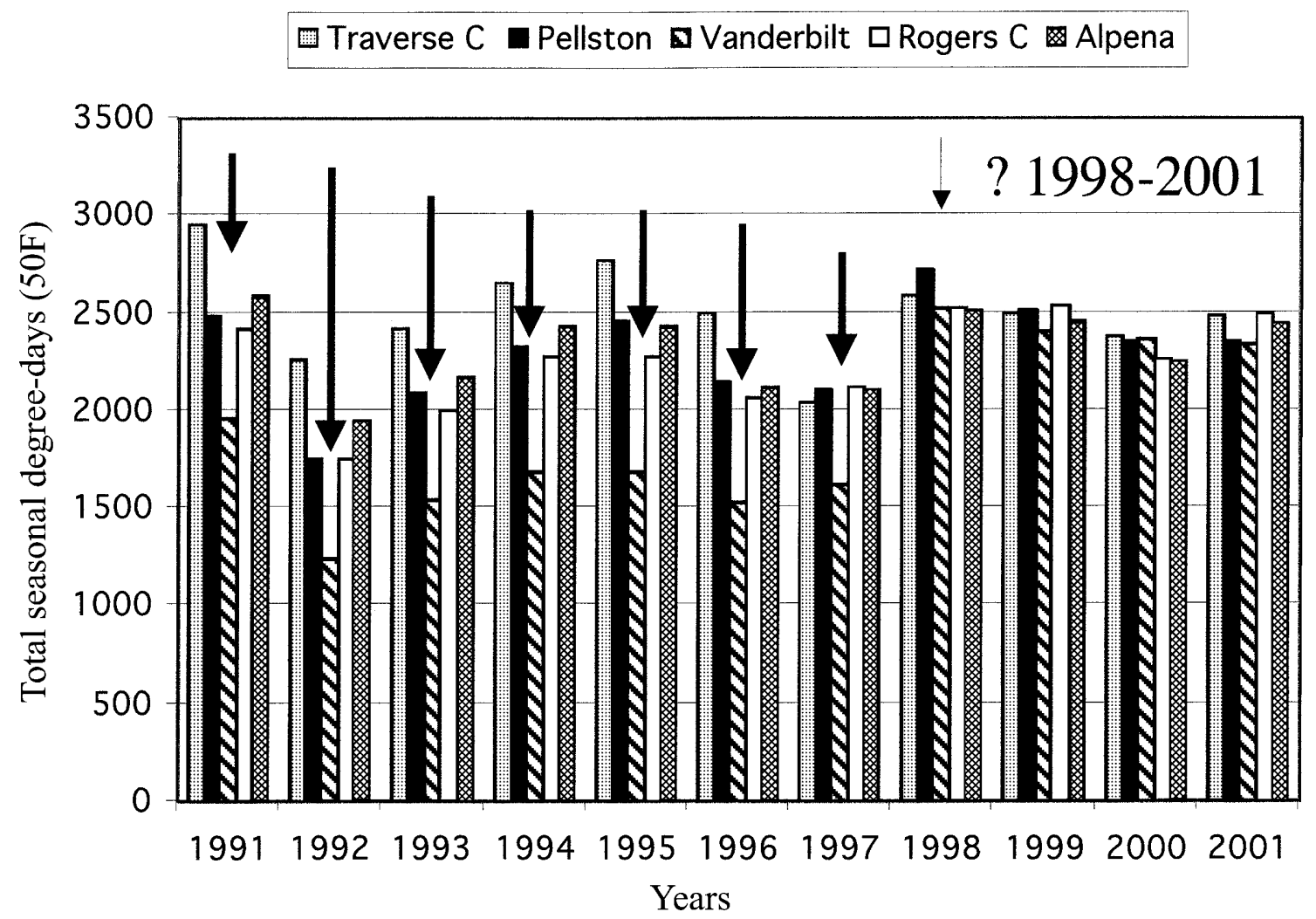

Fig. 4. A representation of the historic "cold pocket" in northern Michigan and its disappearance in the recent 4 years with local climate warming. Vanderbilt is in the center of the cold pocket, and has experienced huge increases in seasonal total thermal accumulations in 1998-2001 (2400-2500 degree days). Before these years the warmest year recorded for this site was in 1991 (and most years before this were less than 1600 total degree days; Fred Nurnberg of MSU Meteorology Center provided data.

described here. The plant species most preferred both in the field and the laboratory by ovipositing females in Alaska ( $P$. balsamifera, A. tenuiflolia, and $P$. tremuloides) and southern Michigan (P. trifoliata, L. tulipifera, and $P$. serotina) are those upon which the larvae grow very fast (Table 1; Fig. 1). In contrast, no significant correlations of oviposition preferences and larval growth rates were observed for northern Michigan or southern Ohio (Fig.1; Table 1). Phenological constraints in the first two sites, but not in the latter two, may reflect strong selection for local specialization as suggested by the voltinism-suitability hypothesis (Scriber \& Lederhouse, 1992). The findings here with both lab and field experiments clearly reflect adult preference and larval performance correlations at certain locations, but not others. If lumped as a species, there would be no correlations detected. However, it has been shown here that environmental consequences of oviposition mistakes vary in severity for different populations of both species, probably reflecting adaptive responses to these different selection intensities.

The preference-performance concept is fundamental to studies of insect-plant interactions and predicts that oviposition preferences should correlate with host suitability for offspring survival, development rates, and success in reproduction (Jaenike, 1978; Scheirs, 2002). While pre- dicted correlations have been found to be strong in some cases, most studies have found little or no correlations, for various reasons (Thompson, 1988, 1996; Nylin et al., 1996; Mayhew, 1997; Cronin et al., 2001; Scriber, 2002). It is also likely that much of the variation reported in preference-performance relations results from innate species-specific differences. However, even within the same species or population, only selected life stages are experimentally evaluated, giving incomplete pictures of critical life history factors (Leather, 1994; Zalucki et al., 2002 for discussion). Another major reason that varied responses to selection pressures show up in preferenceperformance analyses is that the broad geographic perspective (and differing environmental factors that create local mosaics for the species) are rarely considered. Local adaptations and ecologically tight preferenceperformance relationships may be easily altered by things that affect migration and population build-ups such as global warming shown here. Specialized local populations may be significantly altered by these metapopulation source-sink relationships (Singer \& Thomas, 1996; Ronce \& Kirkpatrick, 2001). 
TABle 4. Primary 5-choice array of Michigan plants ${ }^{1}$ for Michigan P. canadensis oviposition preferences. Data presented as means $( \pm \mathrm{SE})$.

\begin{tabular}{|c|c|c|c|c|c|c|c|}
\hline Location and date & Females & Ptr & Fam & Pse & Bpa & Tam & Eggs (n) \\
\hline \multicolumn{8}{|l|}{ MI 1995} \\
\hline "Cold pocket" & (11) & $\begin{array}{r}9.9 \\
+2.9\end{array}$ & $\begin{array}{r}53.0 \\
\pm 8.6\end{array}$ & $\begin{array}{r}15.5 \\
\pm 4.7\end{array}$ & $\begin{array}{r}5.9 \\
+1.8\end{array}$ & $\begin{array}{r}15.7 \\
\pm 7.0\end{array}$ & $\begin{array}{r}36.6 \\
\pm 5.9\end{array}$ \\
\hline Other areas & (33) & $\begin{array}{r}21.5 \\
\pm 3.1\end{array}$ & $\begin{array}{r}34.3 \\
+3.8\end{array}$ & $\begin{array}{r}15.7 \\
\pm 1.9\end{array}$ & $\begin{array}{r}10.6 \\
+2.0\end{array}$ & $\begin{array}{r}17.4 \\
+3.1\end{array}$ & $\begin{array}{r}48.0 \\
+8.2\end{array}$ \\
\hline Alaska 1995 & (13) & $\begin{array}{r}29.0 \\
\pm 6.6\end{array}$ & $\begin{array}{r}14.5 \\
+1.9\end{array}$ & $\begin{array}{r}21.1 \\
\pm 4.6\end{array}$ & $\begin{array}{r}6.6 \\
+1.5\end{array}$ & $\begin{array}{r}28.9 \\
\pm 4.6\end{array}$ & $\begin{array}{r}39.2 \\
\pm 5.4\end{array}$ \\
\hline
\end{tabular}

${ }^{1} \mathrm{Ptr}=$ Populus tremuloides, Fam $=$ Fraxinus americana, $\mathrm{Pse}=$ Prumus serotina, $\mathrm{Bpa}=$ Betula papyrifera, Tam $=$ Tilia americana.

\section{Geographic thermal mosaics and phenological suitability twists}

In addition to latitudinal gradients, it is shown that local (cold pocket) mosaics of preference and performance of Papilio may result from uneven thermal variation within the same latitudinal region (Scriber, 1996a). Furthermore, the relative suitability of different plant species for supporting rapid larval growth and development will depend not only upon the natural seasonal phenological changes, but also on the specific geographical locations (e.g. cold pockets) on the thermal landscape. The phenological twist of ash leaf quality relative to aspen, cherry, and birch is shown here to have different ecological consequences for Papilio in cold pockets than for those outside (Fig. 3). The selection leading to different voltinism patterns of herbivorous insects involves a complex matrix of abiotic factors and biotic responses.

\section{False second generations from hybrid introgression?}

While the two swallowtail butterfly species appear to have different diapause regulating systems (obligate and facultative), the classification of individuals between the first generation flights and second generation flights is sometimes difficult to determine. The occurrence of falsesecond generations (appearing as distinct second flights) at latitudes near the hybrid zone have been an enigma. The number of DD after the first adults take flight are insufficient to produce a true second generation (i.e. these individuals are not derived from the first; Scriber, 1975; Hagen \& Lederhouse, 1985). The propensity of the first generation larvae/pupae to enter pupal diapause (rather than develop directly into a second flight) at latitudes near the hybrid zone would suggest that these populations showing false second flights are really all derived from the previous season (see also Hagen \& Lederhouse, 1985). Such false second flights are most concentrated near the 2400-2600 DD isotherms as shown in central New York State, southwestern Vermont, and across Massachusetts.

Spring field conditions in the US reflect a continually lengthening photoperiod and increasing mean temperatures during the pre-eclosion times for tiger swallowtail butterfly. Doubtlessly, a combination of independent and interactive environmental cues such as temperature and photoperiods modulate the actual diapause induction (Denlinger, 2002) and termination ( Danilevskii, 1961; Beck, 1980) and adult emergence of $P$. canadensis, $P$. glaucus, and introgressed genotypes in the hybrid zone. Results from other laboratory studies (Scriber et al., 2002 b) suggest that diapausing $P$. canadensis emerge first in early summer/late spring, followed by hybrids in a week or two, then by $P$. glaucus individuals. It is logical to suspect that the false second flights might be due to interspecific hybrid introgression.

The reanalysis of various types of hybrid/backcross families demonstrates that morphological wing traits (although genetically based and species-diagnostic) may also be influenced by the process of overwintering in pupal diapause (e.g. perhaps size is affected by months of diapause metabolism; see also Luebke et al., 1988; Scriber, 1990). Diapause appears correlated with (or may partially cause) offspring of hybrids and backcrosses to appear more canadensis-like in forewing lengths and hindwing black band widths. Such diapause/morphology interactions may characterize the early spring (diapausing) versus late (direct developing true second) flights in hybrid zones. However the source of intermediate hybrid-like wing morphology of the false-second (July) flights is not clear. It seems very likely that the source could be interspecific hybrid introgression.

\section{Impact of climate warming}

Recent trends in regional climate warming have been documented throughout the Great Lakes region and New England, with 1998 and 1999 as especially warm years as indicated by seasonal degree-day accumulations. Weather data from transects across the northern Michigan cold pocket can also show considerable year-to-year variation in the growing season degree days (Scriber \& Gage, 1995). The warmest year to that date was 1991, which was followed by one of the coldest in 1992 (Fig. 4). The historically documented cold pocket appears to have basically vanished in the 1998, 1999, and 2000 transects with the warmest years ever recorded in that area (Fig. 4). The center of the cold pocket (Vanderbilt) has recently become as warm as the edges of this transect. It is unlikely that there were any thermal constraints imposed during the past few years on completion of larval development (on any host plants) as clearly done in the cooler 1970 's and early 1980's conditions (Scriber, 1994), as well as in 1992, 1993, and 1994 (Fig. 4). This steady climate warming in the center of the cold pocket will allow us a unique opportunity to evaluate the degree of relaxa- 
tion of strong behavioral ash preference selection gradients (and potential genetic introgression) near the cold pocket. Unlike females from 1991-1995 that placed an average of $40-70 \%$ of their eggs on ash in 5-choice arenas (Scriber, 1996a), the 1996 and 1997 females from the cold pocket (following a warm year in 1995) averaged only $17-18 \%$ each year, reflecting no preferences for ash (Giroux, 1998). Unfortunately, no such 5-choice oviposition studies were done in the period from 1998-2001 to see if these local ash preferring genotypes were completely extirpated or overcome by influxes of $P$. glaucus (Scriber et al., 1998).

The warming trends of the past decade make it the warmest of the last 1,000 years (Hughes, 2000). Temperature accumulations have been used to predict geographic range distributions for at least 100 years (Merriam, 1894; Scriber and Lederhouse, 1992). The climate cold pocket and phenological delays observed in northern Michigan during the early 1990s (Scriber, 1996a; Figs 2 and 3) may be gradually disappearing as the phenological differences between leaves of different tree species is compressed due to warmer springs/summers in the Great Lakes region (Giroux, 1998). Such climatic warming may have more impact on localized specialists such as larch-feeding specialist, Hyalophora columbia, (Scriber \& Grabstein, 1991) than generalist Lepidoptera (Pimm, 2001; Thomas et al., 2001; Warren et al., 2001). It can be seen here, with climate-driven introgression between swallowtail butterflies, that "specialists" may need to be defined by specific individual detoxification or host-location traits rather than by taxonomic categories such as species or even host races (Fox \& Morrow, 1981; Scriber, 1983).

\section{Mating opportunities and sexual selection}

Successful mating of individuals in any population will obviously depend upon isochronic adult phases. While the lifespan of individual butterflies of both species may be as long as 3-6 weeks, most individuals survive for much shorter periods (Scriber et al., 1998b). We have seen for a range of temperatures that $P$. canadensis emerges the earliest, followed by hybrids, and finally by P. glaucus (Scriber et al., 2002b; Scriber et al., in prep). The earliest $P$. canadensis males and females in the hybrid zone may therefore rarely encounter first generation $P$. glaucus individuals and vice versa for later in the season. Interspecific hybridization would be less likely with cool spring temperatures in the range of $12-18^{\circ}$ (that separate the diapause emergence differences between parental types and their hybrids) than warm spring temperatures that would compress the emergence phenologies. However, some long-living $P$. canadensis, combined with fast warming spring temperatures (such as we have experienced during the last 3 years), could place the species in temporal overlap with $P$. glaucus during the first generation across the hybrid zones.

We also know from field tethering experiments with size-matched, interspecific pairs of lab-reared virgin tiger swallowtail butterflies, that $P$. canadensis males in northern Michigan will mate with heterospecific females ( $P$. glaucus) at an even higher frequency than with their own (conspecific) females (Deering \& Scriber, 2002). Since both $P$. canadensis and $P$. glaucus are multiplymating species (both sexes) (Lederhouse \& Scriber, 1987; Lederhouse et al., 1989, 1990), the possibility of conspecific sperm recognition and "cryptic sexual selection" exists for multiply-mated females receiving both conspecific and hetrospecific matings (Eberhard, 1996). However, Stump (2000; and Stump \& Scriber, in prep.) has shown with diagnostic allozymes and sequential analysis of offspring that females do not consistently select conspecific sperm when experimentally mated to males of different species in different sequences. We observed "first male" sperm precedence, "last male" precedence, and "mixed" genotype offspring (some from both first and second male mates). Thus, it appears that neither behavioral mate recognition/selection in the field nor cryptic sexual selection by females (post-mating, prezygotic conspecific sperm selection) provide rigorous interspecific reproductive isolation in the hybrid zone of these butterfly species.

\section{Mating opportunities and synchronous eclosions}

It has been suggested that sexual differences in propensity to diapause, as seen in Papilio here and for other butterflies (Wiklund et al., 1992; Nylin \& Gotthard, 1998), might help promote speciation by making one sex scarce in a given generation (S. Nylin, pers. comm.). We have seen that females of hybrids ( $P$. glaucus $\times P$. canadensis) fail to emerge from diapausing pupae at both high $\left(30^{\circ} \mathrm{C}\right)$ and low $\left(14^{\circ} \mathrm{C}\right)$ temperatures and are delayed by 2 weeks after male emergence at $20^{\circ} \mathrm{C}$ and $26^{\circ} \mathrm{C}$ degrees (Scriber et al., 2002b). Such protandrous temporal separation of Papilio hybrids in conjunction with different (intermediate) eclosion times of hybrids than for parental species types could lead to allochronic reproductive isolation and have implications for the degree and direction of genetic divergence even in sympatry (Feder, 1998; Berlocher \& Feder, 2002). Male protandry in $P$. canadensis and $P$. glaucus could reflect a number of genetic and environmental causes of growth rate variation and pupal size determination (Lederhouse et al., 1982; Oliver, 1983; Pullin, 1986; Wiklund et al., 1992; Nylin, 1992; Nylin et al., 1993; Gomi, 1997; Ayres \& Scriber, 1994), even though all were reared on the same host plant species $(P$. serotina) in the same controlled environmental conditions (Scriber et al., 2002a).

\section{Non-concordant hybrid zone trait clines}

These changing environmental variables and the behavioral/physiological aspects of hybrid interactions make difficult the interpretation of the genetic factors underlying the dynamics of hybrid zones (Shaw et al., 1990; Jiggins \& Mallet, 2000). Preliminary analyses of mitochondrial DNA in central Michigan suggest that these genodynamics may be even more complex, since the maternally-inherited mtDNA of $P$. canadensis may be moving southward, while most allozymes and ecologically-significant traits seem to be moving readily northward (Scriber, 2002; Stump \& Scriber, unpublished). Enzymatic capabilities for detoxification of 
quaking aspen are genetically-based and inherited in a quantitative fashion in interspecific hybrids and backcrosses (Scriber, 1998; Scriber et al., 1989, 1999). However, these aspen phytochemical detoxification traits do not seem to be moving south of the historical hybrid zone in the past 4 years in contrast to extensive movement of tulip tree detoxification abilities (Scriber, 2002). We have observed asymmetrical movement for a variety of other independently segregating trait clines (many of which were previously believed to be species diagnostic). The semi-permeable nature of this Papilio hybrid zone shows that extensive introgression does not reflect concordant trait patterns as seen in sunflowers (Rieseberg et al., 1999). Perhaps these traits may be predicted by the recent (or relevant) differential DD accumulations on the thermal landscape. DD (averaged for the 1980-1989 decade) actually predict population hindwing black band widths (which are diagnostically different for $P$. canadensis and $P$. glaucus) of individuals of 315 populations of Papilio statewide across the hybrid zone of Massachusetts and all of New England better than does latitude (Scriber, in prep.). This correlation presumably reflects the close relationship between the thermally-driven environmental selection and the resulting voltinism-diapause responses of the two swallowtail species and their hybrids throughout this mountainous region.

\section{X-chromosome recombination}

Strong ecological selection after extensive hybrid introgression may contribute to rapid genetic divergence for closely linked traits. It appears that two speciesdiagnostic X-linked allozymes (LDH-100 and PDG-100) have moved with very different success across the historical hybrid zone in Michigan and southwest Vermont (Battenkill River Valley) during the past few years. Northward movement of the X-linked LDH-100 alleles appears to be stopped abruptly at the same areas associated with the northern limits of the true second generation populations (at $2800 \mathrm{~F}$ DD). In contrast, the X-linked PGD-100 and the autosomal HK-100 have moved freely northward for hundreds of kilometers to areas with only 2000-2300 F DD (Scriber, 2002, and unpublished). This lack of association with each other in the hybrid zone suggests alleles at these loci were uncoupled by recombination in hybrid offspring (Hagen, 1990; Scriber, 1994; Hagen \& Scriber, 1995). The X-chromosome does not move as a block in this hybrid zone. If LDH-100 is closely linked on the X-chromosome with the gene for facultative diapause, both would quickly be selected out in the fall from direct-developing individuals in marginally suitable locations ( $<2700$ DD) where their offspring would not successfully reach the diapausing pupal stage before winter. Such appears to be the case for the false second generation near Bennington County, Vermont where $P$. canadensis and $P$. glaucus alleles for PGD and HK have recently become nearly "panmictic", but no LDH-100 nor a true second generation has ever been detected (Scriber et al., in prep).

Pre-diapause induction is largely controlled photoperiodically for P. glaucus, but not for P. canadensis where essentially every individual diapauses (Rockey et al., 1987b; Valella and Scriber, unpublished). Latitudinal trends in the critical photoperiods have been documented for various populations of $P$. glaucus from Florida $\left(27^{\circ} \mathrm{N}\right.$ latitude) to the Great Lakes region ( $45^{\circ} \mathrm{N}$ latitude; Hagen \& Lederhouse, 1985; Rockey et al., 1987b). During the mid-1980s, a boundary between obligate diapausers (canadensis) and direct developing (bivoltine) and facultatively-diapausing glaucus individuals has been observed to correspond to an area near the southern edge of the historical hybrid zone.

As in the high latitude Alaskan populations, strong selection pressures for rapid completion of development may be operational in lower latitude cold pockets due to severe thermal constraints. These limiting thermal resources appear to have selected for rapid larval growth, smaller pupal sizes, bigger eggs and neonate larvae, shorter molt durations at low temperatures (Ayres and Scriber, 1994; Scriber, 1994), and selection of the most nutritious host plant species for oviposition (Scriber \& Lederhouse, 1992; Scriber, 1996a). These localized areas have very few freeze-free days between the last spring and first fall freezes. For example, in northern Michigan $\left(45-46^{\circ} \mathrm{N}\right)$, these cold pockets are classified in the same plant hardiness zone (category No. 3; USDA Misc. Publ. No.1475) as Fairbanks, Alaska. Larvae of various Papilio species exposed to low temperatures are susceptible to freezing death in both early (Tesar \& Scriber, 2002) and late instars (Scriber \& Gage, 1995). The importance of seasonal degree day accumulations as well as both critically low and high temperatures determining the potential range limits of $P$. glaucus and $P$. canadensis has been documented recently (Kukal et al., 1991; Ayres \& Scriber, 1994; Scriber \& Gage, 1995; Scriber et al., 2002b).

The parapatric borders of these swallowtail butterflies comprises the hybrid zone. Natural hybridization has been underestimated as an important source of genetic variation (Arnold, 1997; Mousseau et al., 2000). Recent warming has created extensive interspecific hybrid introgression that is unique in Papilio (Scriber, 1998), which lack the strong cohesive associations of species markers seen in hybrid zones for ground crickets (Rand \& Harrison, 1989), Heliconius butterflies (Jiggins \& Mallet, 2000), and other organisms (Barton \& Hewitt, 1985; Shaw et al., 1990). Various independent trait cline geographic distribution limits (behavioral, physiological, detoxification, and morphological traits) may nevertheless be closely predicted by thermal unit accumulations, whether or not Papilio species boundaries are discernable by concordance of such trait step-clines at the hybrid zone.

ACKNOWLEDGEMENTS. This work was supported in part by the Michigan Agricultural Experimental Station (Project MICL1644) and the National Science Foundation (NSF Ecology DEB-9201122, Ecosystems DEB-9510044, DEB-9981608). Many students and lab colleagues helped collect specimens over these 18 years. We also thank cooperators who consistently provided access to museum specimens or livestock for our rearing/mating operations: Lincoln Brower, Robert Dowell, Jim 
Maudsley, Steve Maclean, Mo Nielsen, Howard Romack, John Thompson, and Wayne Wehling. Chris Leahy and W. Dave Winter kindly provided valuable data from the State of Massachusetts Survey of Butterflies (1986-1990). Matt Ayres and Robert Lederhouse helped with the first year field counts of eggs and larvae on various tree species. Ahnya Redman did the Alaska egg counts. Their help in the design and analysis is also gratefully acknowledged. Molly Brown helped with weighing hundreds of leaf samples from the Michigan cold pocket transects. Mark Deering, Jessica Deering, Jen Donovan, Piera Giroux, Holly Hereau, Matt Lehnert, Michelle Oberlin, Gabe Ording, and Aram Stump assisted in the field or with laboratory electrophoretic allozyme analyses.

\section{REFERENCES}

ARNOLD M.L. 1997. Natural Hybridization and Evolution. Oxford Univ. Press, UK, 215 pp.

Ayres M.P., Bossart J. \& Scriber J.M. 1991: Variation in the nutritional physiology of tree-feeding swallowtail caterpillars. In: Baranchikov Y.N., Mattson W.J., Hain F.P. \& Payne T.L. (eds) Forest Insect Guilds: Patterns of Interactions with Host Trees. Conference proceedings (August 12-20, 1989) Abakan, Siberia, U.S.S.R. USDA Forest Service, Gen. Tech. Report, NE-153, pp. 85-102.

AYres M.P. \& SCRIBER J.M. 1994: Local adaptations to regional climates in Papilio canadensis (Lepidoptera: Papilionidae). Ecological Monographs 64: 465-482.

BaRTON N.H. \& HewtT G.M. 1985: Analysis of hybrid zones Annu. Rev. Ecol. Syst. 16: 497-503.

Beck S.D. 1980. Insect Photoperiodism. $2^{\text {nd }}$ ed. Academic Press, $\mathrm{NY}, 387 \mathrm{pp}$.

BerLocher S.H. \& Feder J.L. 2002: Sympatric speciation in phytophagous insects: moving beyond controversy? Anmu. Rev. Entomol. 47: 773-815.

Bossart J.L. \& SCriber J.M. 1999: Preference variation in the polyphagous tiger swallowtail butterfly (Lepidoptera: Papilionidae). Environ. Entomol. 28: 628-637.

Bradshaw W.E. \& Holzapfel C.M. 2001: Phenotypic evolution and the genetic architecture underlying photoperiodic time measurement. J. Insect Physiol. 47: 809-820.

BRakefield P.M. \& Reitsma N. 1991: Phenotypic plasticity, seasonal climate and the population biology of Bicyclus butterflies. Ecol. Entomol. 10: 291-303.

Cronin J.T., Abrahamson W.G. \& Craig T.P. 2001: Temporal variation in herbivore host-plant preference and performance: constraints on host-plant adaptation. Oikos 93: 312-320.

Danilevskil A.S. 1961: Photoperiodism and Seasonal Development in Insects. English translation 1965. Oliver \& Boyd, London, $283 \mathrm{pp}$.

DeEring M.D. \& Scriber J.M. 2002: Field bioassays show heterospecific mating preference assymetry between hybridizing North American Papilio butterfly species (Lepidoptera: Papilionidae). J. Ethology (in press), published "on line", March, 2002

Deering M.D., Haslitt T. \& Scriber J.M. 2002: Factors affecting diapause termination in Papilio troilus pupae (Lepidoptera: Papilionidae) Holarctic Lepidoptera 8: 43-47.

Denlinger D.L. 2002: Regulation of diapause. Annu. Rev. Entomol. 47: 93-122.

EBerhardt W.G. 1996: Female Control: Sexual Selection by Cryptic Female Choice. Princeton Univ., NJ, 501 pp.

FedER J.L. 1998: The apple maggot fly, Rhagoletis pomonella: flies in the face of conventional wisdom about speciation? In: Howard D.J. \& Berlocher S.H. (eds) Endless Forms: Species and Speciation. Oxford Univ. Press, London, pp 130-140.
Fox L.R. \& Morrow P.A. 1981: Specialization: species property or local phenomenon? Science 214: 887-893.

FutuYMA D.J. 1976: Food plant specialization and environmental predictability in Lepidoptera. Am. Natur. 10: 285-292.

GrRoux P. 1998: Testing the "cold pocket" hypothesis: Oviposition preference in the Canadian tiger swallowtail, Papilio canadensis. M.S. Thesis. Michigan State University, East Lansing, MI, $86 \mathrm{pp}$.

Gom T. 1997: Geographic variation in critical photoperiod for diapause induction and its temperature dependence in Hyphantria cunea Drury (Lepidoptera: Arctiidae). Oecologia 111: $160-165$.

Grossmueller D.W. \& Lederhouse R.C. 1985: Oviposition site selection; An aid to rapid growth and development in the tiger swallowtail, Papilio glaucus. Oecologia 66: 68-73.

HAGEN R.H. 1990: Population structure and host use in hybridizing subspecies of Papilio glaucus: Linkage analysis and significance in hybrid zone. Evolution 44: 1914-1930.

Hagen R.H. \& Lederhouse R.C. 1985: Polymodal emergence of the tiger swallowtail, Papilio glaucus (Lepidoptera: Papilionidae): Source of a false second generation in central New York State. Ecol. Entomol. 10: 19-28.

HAGEN R.H. \& SCRIBER J.M. 1989: Sex-linked diapause, color, and allozyme loci in Papilio glaucus: Linkage analysis and significance in a hybrid zone. Heredity 80: 179-185.

Hagen R.C. \& ScRiber J.M. 1991: Systematics of the Papilio glaucus and $\mathrm{P}$. troilus groups (Lepidoptera: Papilionidae): inferences from allozymes. Ann. Entomol. Soc. Am. 84: 380-395

Hagen R. \& SCRIBer J.M. 1995: Sex chromosomes and speciation in the Papilio glaucus group. In: Scriber J.M., Tsubaki Y. \& Lederhouse R.C. (eds) The Swallowtail Butterflies: their Ecology and Evolutionary Biology. Scientific Publishers, Inc. Gainesville, FL, pp. 211-221.

Hagen R.H., Lederhouse R.C., Bossart J. \& Scriber J.M. 1991: Papilio canadensis and P. glaucus (Papilionidae) are distinct species. J. Lepid. Soc. 45: 245-258.

Hughes L. 2000: Biological consequences of global warming: is the signal already apparent? Trends Ecol. Evol. 15: 56-61.

JAENIKE J. 1978: On optimal oviposition behavior in phytophagous insects. Theor. Popul. Biol. 14: 350-356.

Jirgins C.S. \& MAllet J. 2000: Bimodal hybrid zones and speciation. Trends Ecol. Evol. 15: 250-255.

Kurkal O., Ayres M. P. \& Scriber J.M. 1991: Cold tolerance of pupae in relation to the distribution of tiger swallowtails. Can. J. Zool. 69: 3028-3037.

LEATHER S.R. 1994: Life history traits of insect herbivores in relation to host quality. In: Bernays E.A. (ed.) Insect-Plant Interactions. Vol. V. CRC Press, Boca Raton, FL, pp 175-207.

LECHOwICZ M.J. 1984: Why do temperate deciduous forest trees leaf out at different times? Adaptation and ecology of forest communities. Am. Natur. 124: 821-842.

LEDERHouse R.C. \& SCRIBER J.M. 1987: The ecological significance of a post-mating decline in egg viability in the tiger swallowtail, Papilio glaucus L. (Papilionidae). J. Lepid. Soc. 41: 83-93.

Lederhouse R.L., Ayres M.P. \& Scriber J.M. 1989: Evaluation of spermatophore counts in studying mating systems of Lepidoptera. J. Lepid. Soc. 43: 93-101.

Lederhouse R.C., AYres M.P. \& SCriber J.M. 1990: Adult nutrition affects male virility in Papilio glaucus. Funct. Ecol. 4: 743-751.

Lederhouse R.C., FinKe M. \& SCRIBER J.M. 1982: The contributions of larval growth and pupal duration to protandry in the 
black swallowtail butterfly, Papilio polyxenes. Oecologia 53 : 296-300

Luebre H.J., Scriber J.M. \& Yandell B.S. 1988: Use of multivariate discriminant analysis of male wing morphometrics to delineate the Wisconsin hybrid zone for Papilio glaucus glaucus and P.g. canadensis. Am. Midl. Natur. 119: 366-379.

MATTSON W.J. \& SCRIBER J.M. 1987: Nutritional ecology of insect folivores of woody plants: water, nitrogen, fiber, and mineral considerations. In: Slansky F. Jr. \& Rodriguez J.G. (eds) Nutritional Ecology of Insects, Mites, and Spiders. John Wiley, NY. pp. 105-146.

MAYHEW P.J. 1997: Adaptive patterns of host-plant selection by phytophagous insects. Oikos 79: 419-428.

MerRIAM C.H. 1894: Laws of temperature control of the geographic distribution of terrestrial animals and plants. Nat. Geogr. Mag. 6: 229-238.

MoPPER S. 1996: Adaptive genetic structure in phytophagous insect populations. Trends Ecol. Evol. 11: 235-238.

Mousseau T.A., Sinervo B. \& Endler J. 2000: Adaptive Genetic Variation in the Wild. Oxford Univ. Press, UK.

NYLIN S. 1988: Host-plant specialization and seasonality in a polyphagous butterfly, Polygonia c-album (Nymphalidae). Oikos 53: 381-386.

NyurN S. 1992: Seasonal plasticity in life history traits: growth and development in Polygonia c-album (Lepidoptera: Nymphalidae). Biol. J. Linn. Soc. 47: 301-323.

Nruin S. \& GotTHard K. 1998: Plasticity in life-history traits. Annu. Rev. Entomol. 43: 63-83.

Nylin S., JANZ N. \& WeDELl N. 1996: Oviposition plant preferences and offspring performance in the comma butterfly: correlations and conflicts. Entomol. Exp. Appl. 80: 141-144.

Nylin S., WikLund C. \& WickMan P-O. 1993: Absence of tradeoffs between sexual size dimorphism and early male emergence in a butterfly. Ecology 74: 1414-1427.

Olrver C.G. 1983: Disturbance eclosion sequence in hybrid Lepidoptera. Can. Entomol. 115: 1445-1452.

PIMM S.L. 2001: Entrepreneurial insects. Nature 411: 531- 532.

Puluin A.S. 1986: Effect of photoperiod and temperature on the life-cycle of different populations of the peacock butterfly Inachis. Entomol. Exp. Appl. 41: 237-242.

RAND D.M. \& HARRISON R.G. 1989: Ecological genetics of a mosaic hybrid zone: mitochondrial, nuclear and reproductive differentiation of crickets by soil type. Evolution 43 432-449.

Redman A. \& Scriber J.M. 2000: Competition between gypsy moth, Lymantria dispar, and the northern tiger swallowtail, Papilio canadensis: interactions mediated by host plant chemistry, pathogens, and parasitoids. Oecologia 125: 218-228.

Reiseberg L.H., Whitton J. \& Gardner K. 1999: Hybrid zones and the genetic architecture of a barrier to gene flow between two sunflower species. Genetics 152: 713-727.

RITLAND D.B. \& SCRIBER J.M. 1985: Larval developmental rates of three putative subspecies of tiger swallowtail butterflies, Papilio glaucus, and their hybrids in relation to temperature. Oecologia 65: 185-193.

RoCKey S.J., HAINZE J.H. \& SCRIBER J.M. 1987a: Evidence of a sex-linked diapause response in Papilio glaucus subspecies and their hybrids. Physiol. Entomol. 12: 181-184.

RoCKey S.J., HAINZE J.H. \& SCRIBER J.M. 1987b: A latitudinal and obligatory diapause response in three subspecies of the eastern tiger swallowtail Papilio glaucus (Lepidoptera: Papilionidae). Am. Midl. Nat. 118: 162-168.

RONCE O. \& KirKPATRICK M. 2001: When sources become sinks: migrational meltdown in heterogenous habitats. Evolution 55: $1520-1531$.
SCHEIRS J. 2002: Integrating optimal foraging and optimal oviposition theory in plant-insect research. Oikos 96: 187-191.

SCRIBER J.M. 1975: Comparative Nutritional Ecology of Herbivorous Insects: Generalized and Specialized Feeding Strategies in the Papilionidae and Saturniidae (Lepidoptera). Ph.D. dissertation, Cornell Univ. Ithaca, NY. 289 pp.

SCRIBER J.M. 1982: Foodplants and speciation in the Papilio glaucus group. In: Visser J.H. \&. Minks A.K. (eds) Proc. $5^{\text {th }}$ Int. Symp. on Insect Plant Relationships. PUDOC. Wageningen, Netherlands, pp. 307-314.

SCRIBER J.M. 1983: The evolution of feeding specialization physiological efficiency, and host races. In: Denno R.F. \& McClure M.S. (eds) Variable Plants and Herbivores in Natural and Managed Systems. Academic Press, NY, pp. $373-412$.

SCRIBER J.M. 1984: Insect/Plant Interactions - Host plant suitability. In: Bell W. \& Carde R. (eds) The Chemical Ecology of Insects. Chapman \& Hall, London, pp. 159-202

SCRIBER J.M. 1990: Interaction of introgression from Papilio glaucus canadensis and diapause in producing "spring form" Eastern tiger swallowtail butterflies, P. glaucus. Great Lakes Entomol. 23: 127-138.

SCRIBER J.M. 1991: Differential suitability of 12 Great Lakes tree species for Papilio canadensis (Lepidoptera: Papilionidae) larval survival and growth. Great Lakes Entomol. 24: 239-252

SCRIBER J.M. 1993: Absence of behavioral induction in oviposition preference of Papilio glaucus (Lepidoptera: Papilionidae). Great Lakes Entomol. 26: 81-95.

SCRIBER J.M. 1994: Climatic legacies and sex chromosomes: latitudinal patterns of voltinism, diapause size and host-plant selection in 2 species of swallowtail butterflies at their hybrid zone. In: Danks H.V. (ed.) Insect Life-Cycle Polymorphism: Theory, Evolution and Ecological Consequences for Seasonality and Diapause Control. Kluwer Academic Publ., Dordrecht, Netherlands, pp. 133-171.

SCRIBER J.M. 1996a: A new cold pocket hypothesis to explain local host preference shifts in Papilio canadensis. 9th Intern. Symp. Insects \& Host Plants. Entomol. Exp. Appl. 80: 315-319.

SCRIBER J.M. 1996b: Tiger tales: natural history of native North American swallowtails. Am. Entomol. 42: 19-32.

SCRIBER J.M. 1998: Inheritance of diagnostic larval traits for interspecific hybrids and Papilio canadensis and P. glaucus (Lepidoptera: Papilionidae). Great Lakes Entomol. 31: 113-123.

SCRIBER J.M. 2002: Evolution of insect-plant relationships: Chemical constraints, coadaptation, and concordance of insect/plant traits. Entomol. Exp. Appl. (manuscript in press from invited speaker address)

Scriber J.M. \& GAGE S. 1995: Pollution and global climate change: Plant ecotones, butterfly hybrid zones, and biodiversity. In: Scriber J.M., Tsubaki Y. \& Lederhouse R.C. (eds) Swallowtail Butterflies: Their Ecology and Evolutionary Biology. Scientific Publishers, Inc., Gainesville, FL, pp. 319-344.

SCRIBER J.M. \& GRABSTEIN E.M. 1991: Foodplant processing adaptations in four Hyalophora species (Lepidoptera: Saturniidae): regional and taxonomic specialization. Great Lakes Entomol. 24: 109-120.

SCRIBER J.M. \& HAINZE J. 1987: Geographic variation in host utilization and the development of insect outbreaks. In: Barbosa P. \& Schultz J.C. (eds) Insect Outbreaks: Ecological and Evolutionary Processes. Academic Press, NY, pp. 433-468.

SCRIBER J.M. \& LEDERHouse R.C. 1983: Temperature as a factor in the development and feeding ecology of tiger swallowtail caterpillars, Papilio glaucus. Oikos 40: 95-102. 
SCRiBer J.M. \& Lederhouse R.C. 1992: The thermal environment as a resource dictating geographic patterns of feeding specialization of insect herbivores. In: Hunter M.R., Ohgushi T. \& Price P.W. (eds) Effects of Resource Distribution on Animal-Plant Interactions. Academic Press, NY, pp 429-466.

Scriber J.M., Deering M.D., Francke L., Wehling W. \& LederHouse R.C. 1998b: Notes on the butterfly population dynamics of 3 Papilio species in south central Florida (Highlands County) Holarctic Lepidoptera 5: 53-62.

SCRIBER J.M., KeEFover K. \& Nelson S. 2002b: Hot summer temperatures may stop movement of Papilio canadensis butterflies and genetic introgression south of the hybrid zone in the North American Great Lakes region. Ecography 25: 184-192.

Scriber J.M., DeErINg M.D. \& STump A. 1998a: Evidence of long range transport of a swallowtail butterfly (Papilio glaucus L.) on a storm front into northern Michigan. Great Lakes Entomol. 31: 151-160.

SCriber J.M., Deering M.D. \& Stump A. 2002a: Hybrid zone ecology: geographical and genetic distance influences on behavioral, biochemical, and ecological trait clines of tiger swallowtail butterflies. In: Boggs C., Watt W. \& Ehrlich P. (eds) Ecology and Evolution Taking Flight: Butterflies as Model Study Systems. University of Chicago Press, Chicago, IL. (in press).

Scriber J.M., Giebink B.L. \& Snider D. 1991: Reciprocal latitudinal clines in oviposition behavior of Papilio glaucus and $\mathrm{P}$. canadensis across the Great Lakes hybrid zone: possible sexlinkage of oviposition preferences. Oecologia 87: 360-368.

SCRIBER J.M., HAgen R.H. \& LEDERHOUSE R.C. 1996: Genetics of mimicry in the tiger swallowtail butterflies, Papilio glaucus and P. canadensis. (Lepidoptera: Papilionidae). Evolution 50: $222-236$.

Scriber J.M., Lindroth R.L. \& Nitao J. 1989: Differential toxicity of a phenolic glycoside from quaking aspen leaves by Papilio glaucus butterfly subspecies, their hybrids, and backcrosses. Oecologia 81: 186-199.

Scriber J.M., Weir K., Parry D. \& Deering J. 1999: Using hybrid and backcross larvae of Papilio canadensis and $\mathrm{P}$. glaucus to detect induced chemical resistance in hybrid poplars experimentally defoliated by gypsy moths. Entomol. Exp. Appl. 91:233-236.

Shaw D.D., Marchant A.D., Arnold M.L., Contreras N. \& KoHLMANN B. 1990: The control of gene flow across a narrow hybrid zone: a selective role for chromosomal rearrangement? Can. J. Zool. 68: 1761-1769.

SINGER M.C. \& THOMAS C.D. 1996: Evolutionary responses of a butterfly metapopulation to human- and climate-caused environmental variation. Am. Natur. 148: 9-39.
SlansKy F. \& SCRIBER J.M. 1985: Food consumption and utilization. Chapter 3. In: Kerkut G.A. \& Gilbert L.I. (eds) Volume 4, Comprehensive Insect Physiology, Biochemistry, and Pharmacology. Pergamon Press, Oxford, pp. 87-163.

STUMP A. 2000: Lack of Cryptic Reproductive Isolation between Papilio canadensis and Papilio glaucus and Population Genetics near their Hybrid Zone. MS Thesis. Dept. Entomology, Michigan State Univ., East Lansing, MI, 105 pp.

Tauber M.J. , Tauber C.A. \& Masaki S. 1986: Seasonal Adaptations of Insects. Oxford Univ. Press, NY, $411 \mathrm{pp.}$

TESAR D. \& SCRIBER J.M. 2002: Growth season constraints in climatic cold pockets: Tolerance of subfreezing temperatures and compensatory growth by tiger swallowtail butterfly larvae. Holarctic Lepidoptera 7: 39-44. (in press).

Thomas C.D. Bodsworth E.J., Wilson R.J., Simmons A.D., Davies Z.G., Musche M. \& ConRadt L. 2001: Ecological and evolutionary processes at expanding range margins. Nature 411: $577-581$.

THOMPSON J.N. 1988: Evolutionary ecology of the relationship between oviposition preference and performance of offspring in phytophagous insects. Entomol. Exp. Appl. 47: 3-14.

THOMPSON T.N. 1996: Trade-offs in larval performance on normal and novel hosts. Entomol. Exp. Appl. 80: 133-139.

TDwell P. 1995: Latitudinal Comparisons of Diapause Induction between Populations of Papilio glaucus and Papilio troilus (Lepidoptera: Papilionidae). MS Thesis, Michigan State Univ. East Lansing, MI, $80 \mathrm{pp}$.

VALELLA P. \& SCRIBER J.M. 2002: Latitudinal variation in photoperiodic induction of pupal diapause in the spicebush swallowtail butterfly, Papilio troilus. Holarctic Lepidoptera 8: 37-41. (in press).

Warren M.S., Hill J.K., Thomas J.A., Asher J., Fox R., Huntley B., Roy D.B., Telfer M.G., JeffCoate S., Harding P., Jeffcoate G., Wills S.G., Greatorex-Davies J.N., Moss D. \& Thomas C.D. 2001: Rapid responses of British butterflies to opposing forces of climate and habitat change. Nature 414: 65-69.

WikLund C., WickMan P.-O. \& NYLIN S. 1992: A sex difference in the propensity to enter direct/diapause development: a result of selection for protandry. Evolution 46: 519-528.

Wood T.K., Olmstead K.L. \& GutTMan S.I. 1990: Insect phenology mediated by host-plant water relations. Evolution 44: 629-636.

Yamaga Y. \& Ohgushi T. 1999: Preference-performance linkage in a herbivorous lady beetle; consequences of variability of natural enemies. Oecologia 119: 183-190.

Zalucki M.P., Clarke A.R. \& Malcolm S.B. 2002: Ecology and behavior of first instar larval Lepidoptera. Annu. Rev. Entomol. 47: 361-393.

Received November 9, 2001; revised May 13, accepted May 20, 2002 